\author{
Oleksandr PETRYK
}

\title{
THE IMF PROGRAMS: COUNTRIES' EXPERIENCES AND THE IMPLICATIONS AND PROSPECTS FOR UKRAINE
}

\begin{abstract}
The IMF is the world's leading institution for promoting global economic and financial stability. Unlike other IFl's, the Fund isn't an ordinary lending institution. The IMF holds a pool of member-countries' currencies and an amount of its own foreign reserves and uses this money to provide credit to members when they face economic and financial difficulties or expect them in the near future. A country contributes to the Fund according to a quota based mainly on its relative position in the world economy, including its GDP, trade, inflows of capital and reserves. The Fund's quota-based money holdings may be supplemented by General Resources Account (GRA) borrowing in case of exceptional needs by the member states.

The subject of the article consideration is the new loan toolkit of the Fund, which evolved together with the development of the international financial system.

The acceleration in the modernization of the lending toolkit took place after the 2008 global financial crisis. It corresponded to an increase in the financial needs of some of the member states and focused on safeguarding the Fund's
\end{abstract}

(C) Oleksandr Petryk, 2017.

Petryk Oleksandr, Doctor of Economic Sciences, Professor, Banking University, Kyiv, Ukraine. 
resources. With modification of existing lending instruments, such as the StandBy Arrangements (SBA) and the Extended Fund Facility (EFF), new ones were introduced, including the Flexible Credit Line (FCL), the Precautionary and Liquidity Line (PLL) and Rapid Financing Instruments (RFI).

The IMF also provides loans to a group of poor countries on concessional terms that include zero interest rates, with the goal of promoting sustainable economic growth and reducing poverty in these countries.

The purpose of the article is to formulate the main directions of the necessary structural reforms in Ukraine based on the method of comparative analysis of IMF program results in different countries.

\section{Key words:}

IMF and Ukraine, IMF lending programs, structural reforms, IMF policy, stabilization program Stand-by, Extended Fund Facility (EFF), pension reform, stabilization programs: Ireland, Uruguay, Romania.

JEL: F3, F33.

\section{The main principles of the Fund's crisis programmes}

After the crisis the IMF substantially increased financial assistance to its members, in order to help them meet their financial needs, thereby supporting macro-financial stabilization, promoting reforms and supporting market confidence.

Fund-supported programs are at the core of its assistance to troubled countries, helping them avoid counterfactual scenarios, providing financial buffers, strengthening the policy framework and reducing the risk of contagion.

A key lesson of the last crisis: the IMF needed to increase its own financial resources to a level which could be allow it to serve as a catalyst and help members support economic and financial stability, sustainable growth and market confidence. 
The Fourteenth General Review of Quotas doubled the size of the quotas and significantly increased the Fund's lending capacity to meet the borrowing needs of member states during and after the global financial crisis. The implementation of the Fourteenth Review also allowed the Fund to improve its own financial base by reducing the share of temporary resources (Internet resource).

In 2008-2013, during the crisis and in the period following, the Fund approved financial resources support and corresponding instruments of SDR 420 billion, including both precautionary arrangements and arrangements which allowed members to make lending.

Objectives of Fund-supported programs differed according to each country's specific circumstances but also based on common principles. Particularly, external or internal imbalances are removed through domestic and external price adjustments, improvements in competitiveness and productivity by eliminating labor market rigidities and the implementation of institutional, legislative and structural reforms. There are also fiscal adjustments that improve the policy mix, promote debt sustainability, restructure the banking and non-banking sectors and strengthens the financial supervisory and regulatory framework.

As an international regulator the IMF cares about global-level stability and tries to help the global economy prevent volatility through spillover effects. Fund-supported programs also help the world as a whole and member states in particular carry out rapid adjustments necessary to cover financial gaps and gain time for reducing external and internal imbalances, stabilizing financial system and government finances, enforcing policies and promoting reforms. Not all programs have achieved their final objectives; different countries under the Fund's programs have had different outcomes. While one group of countries adjusted their economies fairly quickly after the start of a program, another group remained exposed to serious vulnerabilities, the need to increase debt limits on the restoration of market access.

Different factors played different roles in different countries. We considered some of them below. Firstly, some programs focused on adjusting external imbalances and currency misalignment. Bigger exchange rate rigidity implied a greater reliance on domestic wage-price adjustments to restore price competitiveness. In practice, however, this is something that is more difficult to achieve due to the rigidity of wage structures and corresponding social tensions. Secondly, programs usually try to reduce fiscal deficits in order to lower the public debt ratio to a sustainable level in the middle term. Where public debt significantly overreaches the risk threshold, the usual recommendation is to restructure it, with private sector serving as a counterpart and in some extreme cases with the involvement of the official sector.

Most of the programs initiated extensive structural reforms, which are typically necessary for internal devaluation, the restoring of competitiveness and sustainable economic growth. The main element of structural reforms under cur- 

and the implications and prospects for Ukraine

rent conditions is improvement of the state institutional framework and state governance. Core issues include anticorruption measures and Anti-Money Laundering (AML). It should be noted that in some cases growth payoffs come from structural reform in the short, medium and long term due to recapitalization processed in the banking sector and real sector modernization and recapitalization.

A crisis usually increases bank balance-sheet risks due to financial and economic factors as well as from a worsening of supervisory arrangements. Progress towards rescuing and recapitalizing troubled financial institutions was relatively slow. Therefore, quick improvement in the supervision and regulation of banking and non-banking financial institutions could stabilize balance sheet shocks. It is an important feature of recent IMF programs.

Fund programs usually produce better outcomes when implemented in cooperation with other IFI's, such as the World Bank and the EBRD. The recent experience in the Eurozone showed good results from cooperation, while recognizing that the speed of progress and practices differ in different countries (Crisis Programme Review).

An important element leading to a favorable outcome is program design, one which takes into account the main problematic initial conditions, such as a high current account deficit, an overvalued exchange rate, high budget deficits, high public and private debt ratios, a fragile banking system and weak government institutions (Petryk, 2014). Usually, external adjustments depend on external demand, export price dynamics and international exchange rate movements. A correct assessment of the external environment is also a key element of program design. Likewise, it also needs to find the optimal trade-off between a bigbang adjustment and a more gradual implementation that takes into account the benefit-cost in the short and the medium term, as well as the socio-political implications for society. Special cases include programs co-financed through Regional Financial Arrangements (RFA) and with members of currency unions. For example, the Fund closely cooperated with an RFA to bring about debt sustainability control and macroeconomic framework responsibility. As for cooperation with currency unions, effective control over monetary, exchange-rate or financial policies focuses on union-wide institutions rather than any particular country under the program.

Social benefits are, as a rule, protected during a program's implementation. Most of the programs were successful in supporting social benefits spending at existing levels or even increasing it (for example, in the small states of the Caribbean and elsewhere). Eurozone programs, however, showed a moderate decline in private spending-to-GDP ratios, as a result of large fiscal adjustments.

Access to Fund resources depends entirely on a country's situation. The dimensions of IMF financing reflect adjustment challenges, financial developments and access to international financial markets. 


\section{Fund lending toolkit, access policy and conditionality}

The Fund lending toolkit has developed over time. All decisions as to access to IMF resources are made and confirmed by its Board of Directors. They are based on a formal request from a member state through a Letter of Intent and a Memorandum of Economic and Financial Policy and need to be supported by a Fund staff assessment of the country's situation, for example, its external and fiscal imbalances, policies' response and its capacity to repay.

The time of SBA is usually one-to-two years, but never more than three. The repayment is due 3.25-5 years after disbursement ends. The SBA is flexible, with phasing and front-loaded access, when appropriate (Petryk, Batkovskyi, 2014).

An Extended Fund Facility (EFF) addresses medium- and long-term comprehensive reforms for Balance of Payments adjustment, fiscal adjustment and debt sustainability. The usual term is three years, with a maximum extension of one year, if necessary. Repayment is due within 4.5 to ten years of disbursement.

A Flexible Credit Line (FCL) provides financial resources to countries with strong fundamentals, appropriate policies and a good track record, to be used for crisis prevention or crisis resolution. The length is 1-2 years and the repurchase period coincides with that of an SBA.

A Precautionary and Liquidity Line (PLL) is a loan instrument which also provides money to member countries with sound economic fundamentals, but with vulnerabilities that prevent the implementation of FCL preconditions. A PLL focuses on eliminating the causes of these vulnerabilities, as well as Balance of Payments problems. As a rule, the design of the PLL permits large and front-loaded financing, if the member country has sound fundamentals and a good track record of policy implementation and commits to keep it in the future.

The Rapid Financing Instrument (RFI) was created as a low-access financial assistance instrument for member countries that face temporary Balance of Payments imbalances but don't need a complex program. RFA volume is restricted to 50 percent of quota per year and 100 percent of quota in total. The timing of the RFA is the same as under the SBA.

The IMF has evolved its access policy to its financial resources over time. This policy mainly tried to find a balance between changes in the demand for financing on the part of member state, especially during crises, and the need to safeguard the Fund's financial resources. Under normal circumstances, the quantitative threshold for loans is determined by a member's quota. Fund access 

and the implications and prospects for Ukraine

policy has developed by taking into consideration stimuli for countries to cooperate at the early stage, in order to prevent balance of payments imbalances and avoid more drastic development.

The principle of exceptional access was developed on the basis of finding a balance between helping members in trouble and the safeguards of the Fund's financial resources. The four criteria for exceptional access were defined:

- A balance of payments pressure on the capital account that cannot be met within existing financing limits;

- A high probability that debt will remain sustainable based on a rigorous and systematic analysis;

- Good prospects for regaining private capital market access while IMF resources are outstanding;

- Strong adjustment plans and institutional and political capacity to carry them out.

The access policy in every individual case also takes into consideration a country's ability to repay on the basis of policy adjustments (other than Fund financing) and the value of Fund credit outstanding, if necessary.

Conditionality is also one of the key elements in the IMF lending toolkit. The set of conditions that apply to loans is what is commonly referred to as Fund conditionality. It helps to achieve program objectives - particularly Balance of Payments adjustment - within a program's period and provides assurances to repay by the borrowing country. Conditionality covers the design of a program, as well as specific tools of monitoring.

Perhaps an even more crucial element for the program's success is the ownership of the country-borrower authorities. The ownership concept (Mohsin, Sharma, 2001) is based on the strong foundation of the principal-agent theory and the precept that the agent will do a better job and will achieve the objectives if these objectives coincide with those of the principal. Otherwise, due to asymmetric information, the agent might tend to pursue his own interests rather than those of the principal. Implicitly, the ownership concept of the Fund programs refers to a situation when the policy content of the program is similar to what the authorities would choose absent Fund participation. In other words, a country's authorities «own» the program if they share its spirit and really want to achieve the program objectives, rather than formally implement items in their letter of intent.

The Fund also has developed a complex system for doing assessments of financial programs by member countries (Goldsbrough, 2015). The two main pillars of the country self-evaluations system: Ex-post assessments (EPAs) of Longer-Term Program Engagements (LTPEs) and Ex-Post Evaluations 
(EPEs) of Exceptional Access Arrangements. Although detailed objectives of these approaches differ, they both follow similar procedures in evaluating program design, the Fund's engagement effectiveness, the authorities' ownership in the program and lessons from its outcome.

In 2002 the Board of Directors, during its discussion of Access Policy in Capital Account Crises, approved the EPE, which determines the consistency of programs with Fund policies and program review (IMF Financial Operations). This review must provide clear answers to the following questions: (i) were the macroeconomic strategy, program design and financing appropriate to the challenges faced by the member in line with Fund policy, including exceptional access policy?; and (ii) did outcomes meet program objectives? As part of question (i), EPEs were expected to assess the justification for exceptional access, especially with regard to four criteria (exceptional balance of payment pressures, debt sustainability assessment, reassessing capital markets and prospects for success in view of shortcomings or risks).

Some specific measures, including new procedures to strengthen the Fund's «due diligence» for countries with LTPE through systematic ex post assessments, were endorsed by the Board of Directors in 2003. EPAs are expected to provide "an analysis of the economic problems facing the country, a critical and frank review of progress during the period of Fund-supported programs and a forward-looking assessment that takes into account lessons learned and presents a strategy for future Fund engagement». (Goldsbrough, 2015).

Each country evaluation report is focused on quality assessment and taking into consideration criteria such as: (1) the rationale for IMF program involvement; (2) program design; (3) effectiveness of IMF involvement, including the appropriateness of conditionality; (4) forward-looking strategy; and (5) overall judgment on the report, including the extent to which it identifies clear lessons. In order to maximize the scope for comparisons, the criteria have been designed so that most are applicable to both EPAs and EPEs, but some are applicable to only one type of report, reflecting mandates in their respective guidelines. For example, only EPA reports are assessed on how well they investigate the reasons for LTPE and the impact of such engagement on domestic institutions; only EPEs are assessed on how well they investigate the justification for exceptional access and the role of the IMF in managing the crisis. 


\section{The Fund's policy evolution}

From time to time the world takes a precise look at the Fund. In the past, during the Mexican and Asian crises, some economists strongly criticized the Fund for bad foresight, as well as for severe fiscal and monetary contractions during Fund programs, which undermined economic growth. Particularly, Jeffrey Sachs (Sachs, 1997), Joseph Stiglitz (Stiglitz, 2002) and others criticized the Fund for «market fundamentalism». Stiglitz accused the IMF of being driven by a belief in the perfection of the markets and the imperfection of governments.

The past two decades have been really challenging for the Fund, a period of rapid globalization and drastic changes world economy and financial markets. As a consequence, the Fund has made important and far-reaching adjustments and in its policies. Although the Fund's objective- international financial stability remains the same, its approaches and policy tools are changing drastically in the context of the modern global economy. As a leading international financial institution, the Fund constantly re-evaluates its own policies and thinking in light of new developments.

The Fund now focus more on maintaining a credible medium-term fiscal framework for member states, one that provides confidence for the markets that public debt could be repaid without very high inflation.

The IMF also looks more carefully at capital flows, especially when high inflow could provoke domestic credit booms and financial instability and expose a country to financial risk when the direction of the flow is reversed.

Another important lesson for the Fund's approach is the inextricable link between financial (and especially banking sector) and macroeconomic stability and sustainable growth. Usually banks grow bigger and use other sophisticated financial instruments and need more diversification against risks. In this connection banking regulation and prudential supervision are crucial in the Fund's program.

For the Fund it is now more important to prevent the emergence of crises rather than effectively resolve them later. The Fund analyses of a country's economic prospects and possible risks is available to its authorities, so that they make economic policy changes and avoid potential weaknesses in implementation.

Economic research and an international statistic database are an evermore important part of the Fund's functions. The Fund's surveillance work gives it a unique cross-country perspective. It is the one institution that has access to relevant information about national economic data and policies.

The Fund's active functions - surveillance, research, technical assistance and financial support - have a common goal: to deliver economic and financial stability and lay the basis for sustained growth for all member states. 


\section{Countries' experience under the Fund's programs}

Some programs are successful, well designed and achieve all their objectives; others are not and do not. We shall consider some of the latter.

\section{Ireland}

In 2008 Ireland faced the deepest economic crisis in its recent history. The problems of low growth, doubts about fiscal sustainability and a fragile banking sector were feeding on each other, undermining confidence.

Ireland had a long history of exceptionally strong performances. Real GDP growth averaged around 5 percent and employment increased strongly for several decades prior to 2000 , as it benefited from a successful integration into the world economy. High inflows of FDI triggered growth in exports, which expanded to more than 100 percent of GDP. Entry to the Eurozone triggered a drop in interest rates; as a consequence, the economy boomed, supported by a large credit expansion and a rise in property prices due to the wealth effect. Rising wages and prices depressed Ireland's competitiveness, leading the current account from a balance in 2000 to deficits ( 6 percent of GDP in 2008). Credit to the private sector expanded by 20 percent per annum during 2002-07 and total assets of domestic banks reached exceeded 520 percent of GDP by 2008.

The global crisis of 2008 hit the Irish banking sector especially hard. Its difficulties and the bursting of the real estate bubble took their toll on the broader economy. Real GDP contracted nearly 10 percent in 2008-10, led by a 40 percent collapse in investment, in particular in construction.

As the banking crisis escalated, liquidity support provided by the Euro system increased sharply.

The initial crisis response proved insufficient to stabilize the economy: the Irish authorities requested a Fund-supported program in late 2010.

In support of an Irish adjustment program and in parallel with Ireland's European partners, the IMF provided an EFF arrangement with exceptional access of SDR 19.466 billion (2,321.8 percent of quota), covering the period from December 2010 to December 2013. As part of a broader financing package, the program focused on addressing the banking crisis, in order to break the adverse feedback loop between banks, the sovereign sector and the real sector. Fiscal targets were calibrated so as not to unduly undermine growth, while ensuring progress toward fiscal sustainability over the medium term. The program risks 

and the implications and prospects for Ukraine

were regarded as high. A large amount of external financing was a key element of the crisis response.

The access request to an extended arrangement was justified by a large and medium- term BoP need and included a buffer to manage financial sector risks.

At the time of the EFF approval, staff argued - and the Board agreed that all four criteria for exceptional access were met (electronic resource).

Program implementation was very effective. The EFF arrangement was successful in stabilizing the financial sector, reducing its size and containing systemic risks. The public debt and deficit developments were also broadly as anticipated. Low-cost market access for the sovereign was regained by the end of the program period, benefitting also from actions at the wider euro area level. However, unemployment remained high and domestic demand was lower than programmed, amid an external environment that was much more challenging than originally projected. As was anticipated to some extent at the outset, substantial further efforts are needed in the post-program period to reduce significant remaining vulnerabilities, in particular in the fiscal area and the banking sector.

Despite some problems, such as high unemployment and debt, which were not completely solved during the program period, program outcome was considered a success. The main program objectives had been met and the Irish economy regained financial stability. Ireland is also on track to maintain its high growth record during the post-program period.

The lessons learned from Ireland's cooperation with the Fund under the EFF are drawn to a good extent from what worked well and the factors that contributed to Ireland's very strong performance vis-à-vis program objectives. However, it's necessary to point out that not all of these lessons are simply adaptable to other Fund program cases; as always; country-specific circumstances need to be considered carefully. In particular, Ireland's relatively strong capacity and (in most areas) robust institutions are likely to make some lessons less applicable to the typical SBA/EFF arrangement, where constraints in these areas tend to be more prevalent.

Key lessons to be learned from the Ireland program:

- Authorities' ownership. The EFF arrangement supported for the most part a home-grown policy program; in Ireland, implementation was already underway before the Fund-supported program commenced. Wide political commitment made for a more effective policy response and reform implementation.

- In a banking crisis, strong actions upfront- credible asset quality and liquidity assessments and a well-capitalized banking system - are critical. The asset quality and liquidity reviews, designed by Irish au- 
thorities in close cooperation with the Troika team and with experienced private sector involvement, established early on credibility with market participants.

- Set realistic targets and meet them. While always an important objective, meeting program targets is particularly relevant for re-assuring private capital markets. Consistently implementing its commitments allowed Ireland early on to separate itself from other program countries in the euro area. Establishing a realistic but conservative macroeconomic framework was also critical in this regard.

- Focus conditionality on key challenges. The program design with regard to conditionality should focus on the main challenges facing the economy (in Ireland's case, the financial sector and selected fiscal issues) and the setting of priorities as to measures and reforms.

- Communicate effectively. While technical expertise is vital for the right diagnosis and in identifying the appropriate policy response, communicating the strategy is also crucial. Public understanding of program objectives and society support are necessary for program success.

\section{Uruguay}

After the deep South American regional crisis of 2002, which was triggered by Argentina's crisis and default, Uruguayan authorities asked for two SBA programs from the Fund back-to-back and started a series of reforms, with the goal of building a stronger and more resilient economy. During the first program, in 2002-2005, authorities focused on economic and financial stabilization to overcome the consequences of the crisis (electronic resource). They made essential progress towards stabilizing the banking system, as well as fiscal and debt position stabilization and the restoration of strong economic growth. GDP growth was 12 percent in 2004 and 6 percent in 2005. The international community supported these efforts and provided large financing relative to Uruguay's economy during the first SBA.

A second three-year SBA was approved in mid-2005, aiming to improve upon the progress of the preceding program. In the middle of the second SBA term Uruguay made considerable progress, further stabilizing its banking system, improving its external position more than expected, implementing structural reforms and strengthening the economy.

In November 2006 Uruguay's authorities decided that they would shortly repay all outstanding obligations to the Fund and cancel the current SBA. Full repayment of SDR 727 million (US\$1.1 billion) was made on November 30, 2006, shortly after the completion of the fifth and sixth reviews; furthermore, they an- 

and the implications and prospects for Ukraine

nounced that Uruguay would not be making any associated purchases. The authorities' motivation for requesting the completion of the pending reviews was closure - a final review to confirm policy performance and signal commitment to macroeconomic stability and structural reform beyond the timelines and deadlines of Fund conditionality.

Economic outcomes were remarkable. GDP growth was greater than expected and was projected to reach around 6 percent in 2006, two points higher than envisaged in the program. Inflation, which had been pushed up by higher oil prices and drought, eased to 6 percent and remains within the programmed target range. Capital inflows and renewed market access have permitted a substantial increase in net international reserves, which currently exceed the level programmed for the end of the arrangement in 2008. Monetary and fiscal policies have been implemented in accordance with the program. All quantitative performance criteria were met through end-September, except for the ceiling on public debt (while gross debt was higher than programmed, reflecting faster than expected access to market borrowing, net debt was not) (electronic resource). In the structural area, there was progress in financial sector reforms and, most importantly, the long-awaited tax reform. Uruguay's success was based on the implementation of a complex and consistent reforms package.

In the fiscal area, the government had submitted to Congress a five-year spending plan, complete with revenue projections and deficit targets consistent with the program's fiscal targets. The plan was approved. Authorities prepared and - following approval by Congress - implemented comprehensive tax reform. They also began to implement the first stage of pension reform, designed for the military and for bank employees.

In the financial sector Uruguayan authorities passed through Congress and started to implement three important laws meant to extend appropriate autonomy to the central bank, strengthen the regulation of the financial system and provide a suitable bank resolution framework.

Monetary authorities also adopted an action plan to address the financial situation of BHU (a big mortgage bank) consistent with minimizing systemic risks and contingent fiscal costs. NPL was decreased and the banking system, including $\mathrm{BHU}$, was adequately capitalized.

The authorities prepared an agenda for growth-enhancing reforms (including a timetable) and proceeded with their implementation. Meanwhile, Congress approved a bankruptcy law.

The authorities also created a private-sector relations office at the Ministry of Economy and Finance (MEF) and secured the adoption of a detailed plan to strengthen government procurement procedures. 


\section{Romania}

Following the crisis of 2008-09 Romania had one of the lowest levels of per capita income in the region and a notably slow pace of convergence compared to its peers. In order to boost investment and restore economic growth the country's authorities focused on macroeconomic stabilization and structural reforms. In particular, the low efficiency of the main network industries (primarily energy and transportation) and, more generally, of the sizable SOE sector were, together with poor governance, the most evident problems hindering Romania's growth prospects.

Romania requested a Stand-By Arrangement (SBA) in order to restore market confidence by eliminating fiscal and external imbalances, while launching a package of reforms to achieve medium-term fiscal sustainability. The SBA was approved in May 2009, with an exceptional access of SDR 11.443 billion, equivalent to $1,110.8$ percent of quota - one of the largest in Fund history at the time, with co-financing from the EU (electronic resource). The program sought to stabilize the Romanian economy through a significant reduction in fiscal and external imbalances and the strengthening of the financial sector. The strong fiscal structural component aimed to improve long-term fiscal and external sustainability.

Large front-loading, strong ownership, the correct prioritization of reform and a flexible program design were the main components of a successful implementation of the program's first phase. The rapid restoration of market confidence and he return to financial market access also supported the program. Finally, the program achieved its main objectives - strong fiscal adjustment, sustainable improvement of the banking system and a well-balanced monetary policy of the Central bank, which helped to quickly increase international reserves. Medium-term fiscal sustainability was anchored by the obligation under the EU's Stability and Growth Pact. All reviews under the SBA were successfully completed, with the exception of a delay in the completion of the second review.

However, an uncertain external environment, combined with the need for further fiscal adjustment, still posed significant risks to the country's financial stability and economic recovery, at a time when initial repayments to the Fund were coming due.

Despite successful stabilization Romania, needed more deep structural reforms and faster adaptation to EU conditions.

In March 2011, Romania requested a successor Stand-By Arrangement (SDR 3.1 billion, 300 percent of quota), in order to continue the economic adjustment initiated under the 2009 SBA. 
The key objectives of the new program were to create precautionary safeguards against external shocks, to continue fiscal consolidation and boost structural reforms. The program objectives were supported also by the European Union.

As a whole, the second SBA was as successful as the first in preserving macroeconomic stability and advancing economic adjustment; progress on the structural reform agenda, however, was uneven (electronic resource). Despite a complex political situation and a more challenging external environment than initially envisaged, sustained fiscal consolidation efforts allowed Romania to exit the EU Excessive Deficit Procedure (EDP) in 2013. Although Romania, in general, achieved progress, some problems remained. Particularly, progress towards reforming the SOE sector and improving governance was limited, while political instability had a negative effect on further structural reform implementation.

\section{Ukraine}

\section{SBA 2008 and SBA 2010}

After the deep downturn during the global financial crisis of 2008-09, Ukraine's economy started a moderate recovery, while facing significant financing and adjustment needs. In 2009 Ukrainian GDP contracted by 15 percent, the domestic currency, the Hryvnia, devalued by around 60 percent, declining confidence in the currency and the banking system led to a mass outflow of deposits. Ineffective state institutions and weak policy implementation exacerbated the already difficult economic situation. In early November 2008 Ukraine received exceptional access support under a front-loaded two-year SBA. The program was designed to include compromises that took into consideration the extreme circumstances - lack of time, a low level of ownership and weak institutional governance. The main objectives of the program were to quickly stabilize the banks and secure adjustments of the high macroeconomic imbalances. Together with the difficult economic environment, the program's implementation was exacerbated by sharp political divisions, an extremely weak institutional capacity and a high level of corruption. Only two of the envisaged eight reviews were completed. The 2008 program went off track in the fall 2009, as commitment weakened ahead of the January 2010 presidential elections and fiscal policy diverged further from program objectives. Short-term stabilization was achieved; mediumterm objectives, however, lagged. The banking system stabilized, sovereign default and government arrears to households were avoided, but fundamentals and unperformed state institutions stalled. Key lessons to be taken from the failure of the 2008 SBA program were: a lack of ownership and weak medium- term structural reforms performance. The banking system remained fragile. Exchange rate 
ISSN 2519-4070

policy rapidly returned the local currency to a de-facto peg at the new level of around 8 hrivnia per dollar, after devaluation by 60 percent. Because of an absence of energy sector, social, fiscal and pension reforms, fiscal deficit quickly widened again, same as the current account after the attenuation of devaluation effect.

In early 2010 the new government again reached agreement over exceptional access to Fund resources, a new 29-month SBA (SDR10 bln. or 729 percent of quota). The program was approved in line with the Board's decisions on modified exceptional access criteria. The key objectives of the new program were to restore banking sector soundness, introduce a more flexible monetary policy framework, restore market confidence and consolidate external and public sector balances, with particular focus on energy sector reform, increasing the country's resilience to shocks and bolstering the financial sector. The SBA also aimed to restore confidence in fiscal sustainability by reducing the general government deficit through a combination of revenue and spending measures, a reduction in Naftogaz's deficits through energy tariff increases (gas and heating) and structural fiscal reforms. To increase the country's resilience to shocks, the program envisaged an increased focus on domestic price stability (with an eventual move towards inflation targeting) and greater exchange rate flexibility, which could serve as a first line of defense against external shocks.

Key structural non-performed reforms of the 2008 SBA remained relevant and were incorporated into the new program, as prior actions (electronic resource) had focused on fiscal consolidation, energy tariffs, central bank independence and restoring and safeguarding banks' soundness through recapitalization and strengthened supervision. The main objective of the program was to return public finances onto a sustainable path. Three reforms were at the core of medium-term fiscal consolidation strategy: (i) budget reform, including public expenditure optimization and public administration and tax reform, (ii) energy sector reform, which cutting the financing of Naftogaz from the state budget and (iii) pension reform that might help ease social expenditure burden on the budget. The program sought to protect social assistance spending for the poor and public investment, in order to avoid stymieing the nascent recovery.

Although some initial stages of sectoral reforms were completed successfully and temporary macroeconomic stabilization of the economy as whole was achieved, Ukrainian authorities delayed or even stopped completed the next steps of critical reforms, including pension reform, the establishment of an automatic VAT refund process, and raising energy tariffs. Bank restructuring remained incomplete and banking system continued to be characterized by regulatory forbearance and weak enforcement of existing laws and regulations. Despite the de jure official shift in the NBU mandate under the program, the monetary policy framework did not change throughout the program and the exchange rate de facto remained the nominal anchor.

Resistance to raising energy tariffs and implementing necessary fiscal adjustment measures prevented the completion of the second review. After this 

and the implications and prospects for Ukraine

failure in 2011, the general government deficit outturn in 2012 was 4.5 percent of GDP, 2 percentage points higher than originally programmed (and 2.7 percentage points higher than the revised deficit target proposal discussed in 2011). Consequently, the program's main fiscal objective - putting public finances on a more sustainable footing - was not realized and the foundation for sustained growth were still missing.

Despite some separate achievements under the 2010 SBA program, the overall results were disappointing. With the program going off-track due to a lack of ownership and weak governance (electronic resource). Like most previous Fund programs in Ukraine, the 2010 program went off-track before completion.

\section{SBA 2014}

After the Maydan events and with new political forces coming to power, Ukraine faced a severe contraction of economic activity, challenges from the fiscal and debt situation, financial turmoil and the loss of access to foreign financial markets. But more challenging for the country was Russia's annexation of the Crimea and the start of military tensions in the East of the country. An overvalued exchange rate, a substantial budget deficit and sizable losses in the energy sector had put Ukraine on a highly unsustainable course, with a large and rising current account deficit and a rapid loss of foreign exchange reserves. Under these circumstances, with significant external and public sector payments falling due, mounting pressure on the hryvnia and reserves at critical levels, the NBU allowed the exchange rate to float in February 2014. (See Table 1).

The sharp devaluation of the hryvnia heightened uncertainties and geopolitical risks weakened bank and corporate balance sheets, triggered bank deposit withdrawals and fueled capital flight. Under these circumstances, Ukraine requested a 24-month SDR 10.976 billion (about \$17 billion, which covered over 60 percent of Ukraine's financing needs) exceptional access Stand-By Arrangement (SBA) in April 2014 (electronic resource)The approved level of access under the SBA was «exceptional,» in that it exceeded the Fund's normal access limits. Additionally, Ukraine also requested financial assistance from the international community in order to meet its financial obligations, including repayments to the Fund. Under the program, nearly $\$ 15$ billion was pledged by other official creditors; Fund staff projections foresaw Ukraine regaining access to market financing in later program years.

The SBA focused on stabilizing the macroeconomic situation, implementing structural reforms to strengthen governance and transparency and laying the foundation for robust and balanced economic growth over the longer term. Reforms were aimed at achieving external sustainability, ensuring financial stability, fixing public finances, rationalizing the energy sector and improving the business environment. 
Table 1

\section{Ukraine: main macroeconomic data}

Common information: population around $42 \mathrm{mln}$. GDP per capita (current prices): $\$ 2,087$, GDP per capita (by PPP): $\$ 8,230$ unemployment $-9,0$ percent.

Relation with IMF: four-year arrangements under Extended Fund Facility (EFF) in amount of SDR 12.348 bln. (\$17.5) or $614 \%$ of quota. Quota in the Fund: SDR $2,011.8(0.42 \%$ from total), total credit outstanding the Fund: SDR $8.893 .7 \mathrm{bln}$. (\$12.526 bln.) on Aug 31. SDR $=\$ 1.41$

\begin{tabular}{|l|c|c|c|c|c|c|c|c|}
\hline & 2014 & 2015 & 2016 & 2017 & 2018 & 2019 & 2020 & 2021 \\
\hline $\begin{array}{l}\text { Real GDP } \\
\text { growth (\%): }\end{array}$ & $-6,6$ & $-9,8$ & 2,3 & 2,2 & 3,2 & 3,5 & 4,0 & 4,0 \\
\hline $\begin{array}{l}\text { Inflation } \\
\text { (eop \% ): }\end{array}$ & 24,9 & 43,3 & 12,4 & 14,4 & 7,0 & 6,0 & 5,0 & 4,0 \\
\hline $\begin{array}{l}\text { Fiscal bal- } \\
\text { ance } \\
\text { (\% GDP) }\end{array}$ & $-4,5$ & $-1,2$ & $-2,2$ & $-2,4$ & $-2,5$ & $-2,3$ & $-2,1$ & $-2,0$ \\
\hline $\begin{array}{l}\text { Public debt \& } \\
\text { guarantee } \\
\text { (\% GDP): }\end{array}$ & 70,3 & 79,3 & 81,2 & 79,9 & 85,3 & 78,1 & 71,6 & 65,6 \\
\hline $\begin{array}{l}\text { Current ac- } \\
\text { count } \\
\text { (\% GDP): }\end{array}$ & $-4,2$ & $-0,3$ & $-3,6$ & 4,0 & $-3,0$ & $-2,4$ & $-2,3$ & $-2,9$ \\
\hline FDI (\% GDP): & 0,2 & 3,3 & 3,6 & 1,7 & 2,5 & 3,3 & 3,6 & 3,4 \\
\hline $\begin{array}{l}\text { Total external } \\
\text { debt (\% GDP) }\end{array}$ & 95,4 & 130,0 & 123,8 & 119,8 & 126,3 & 114,3 & 104,6 & 95,8 \\
\hline $\begin{array}{l}\text { Official re- } \\
\text { serves (months } \\
\text { of imports) }\end{array}$ & 1,8 & 3,1 & 3,4 & 3,7 & 5,8 & 5,4 & 5,2 & 5,0 \\
\hline $\begin{array}{l}\text { Exchange rate } \\
\text { (ave) }\end{array}$ & 15,8 & 24,0 & 26,6 & 27 & 30,7 & 31,6 & 31,0 & 31,7 \\
\hline $\begin{array}{l}\text { Real effective } \\
\text { exchange rate } \\
\text { (\% chang) } \\
\text { 2017-2021 } \\
\text { IMF's and } \\
\text { NBU's as- } \\
\text { sessment }\end{array}$ & $-20,9$ & $-11,2$ & 0,2 & 0,4 & 1,6 & 4,0 & 3,0 & 3,5 \\
\hline
\end{tabular}



and the implications and prospects for Ukraine

The program had relatively more upfront structural conditionality, including 12 prior actions upon approval, to strengthen implementation by taking into account Ukraine's poor track record under past arrangements. The fiscal objectives were broadly appropriate, aiming to maintain priority spending and initiating medium-term fiscal adjustment. Priority actions in the financial sector were to assess bank solvency and resilience through stress-testing for the top 50 banks, provide liquidity to solvent bank if necessary, restore a strong supervisory and regulatory framework and improve the banks' capacity to resolve NPLs. The SBA also aimed to gradually eliminate Naftogaz losses by implementing staged tariff increases and improving payment discipline. To mitigate the price shock on households, the tariff increases were appropriately accompanied by measures to protect the most vulnerable. A dispute between Naftogaz and Gazprom in early 2014 further weakened program buffers; however, Ukrainian authorities negotiated in good faith and met program pre-conditions.

Despite the fragile political equilibrium and the continuation of conflict in the East, meaningful and difficult reform steps under the program were nevertheless undertaken.

The first stage of energy tariff increases was implemented successfully; commendable progress was made in improving Naftogaz governance and finances. A flexible exchange rate was maintained, albeit with occasional interventions. In the financial sector, tangible steps were taken to identify weaknesses in banks and several were decisively resolved. The authorities' comprehensive diagnostic study on corruption and governance helped lay a strong foundation for reforms. Although the SBA was short-lived and did not achieve many of its goals, it served as an anchor for economic policies in a difficult and uncertain economic and political situation.

Financing needs ballooned towards the end of the program, ultimately making the program objectives unachievable within its timeframe. The Fund recognized at that stage that Ukraine's financing needs would be larger and more protracted than covered under the SBA, requiring deeper structural reforms and a debt restructuring operation to ensure sustainability. To that end, the SBA was replaced with the EFF, which included additional financing and a longer repayment period. The international community also provided additional financing and the authorities started debt restructuring talks with Ukraine's main creditors.

\section{SBA 2014 was replaced by IFF 2015}

After macroeconomic stabilization under the SBA, Ukraine initiated a package of deeper and more comprehensive reforms. In the very unstable sociopolitical situation, authorities took the first steps in towards fiscal adjustments, which included restructuring of the energy sector, increases in energy tariffs and cuts in unproductive budget expenditures. The NBU introduced a flexible ex- 
change rate regime and stabilized the financial system. However, geopolitical and economic shocks pushed real GDP into a decline, while a drop in prices for Ukraine's main export items led to a deterioration of its current account. An escalation of the conflict in the East during the first year of the SBA led to a significant loss of investor confidence and disrupted industrial production and export capacity. Capital outflow depleted foreign reserves and led to sharp exchange rate depreciation and a widening of the financial gap. Banks again came under increasing pressure; the public debt dynamic worsened. In this situation Ukraine needed a new economic reform program to restore stability and lay the basis for robust growth over the medium term. In the first quarter of 2015 Ukraine requested support to an Extended Arrangement under EFF. Its authorities saw the EFF program as a way to improve the policy mix in order to return to sustainable economic growth and extend the comprehensive structural reform agenda (electronic resource).

In particular, policy would focus on:

- securing financial stability, including the implementation of a new flexible exchange rate policy framework and a strategy to strengthen banking system soundness (recapitalization, the liquidation of related party lending and resolution of impaired assets);

- Strengthening public finances, which would in turn support fiscal consolidation in coming years. Together with energy sector reforms and the announced debt operation, this would reduce fiscal imbalances and achieve public debt sustainability with high probability. Social protection schemes would be revamped to protect the poorest and alleviate social costs.

Advancing structural reforms designed to improve the business climate, attract investment and enhance Ukraine's growth potential. Energy sector reforms were to include Naftogaz restructuring; governance reforms, including anticorruption and judicial measures, deregulation and tax administration reforms; comprehensive pension reform and reforms of state-owned enterprises to improve corporate governance.

The continued success of the new EFF program was also important from point of view of improve Ukraine's credibility, which had suffered when previous programs were not brought to an end and objectives left unmet.

On March 11, 2015 IMF Executive Board approved a four-year extended arrangement under the Extended Fund Facility for Ukraine. The arrangement amounts to the equivalent of SDR 12.348 billion (about US $\$ 17.5$ billion, 900 percent of quota) and was approved under the Fund's exceptional access policy. The Board also took note of Ukraine's decision to cancel the Stand-By Arrangement (SBA) that was approved on April 30, 2014. The approval of the extended arrangement under the EFF enables the immediate disbursement of SDR 3.546 

and the implications and prospects for Ukraine

billion (about US $\$ 5$ billion), with SDR 1.915 billion (about US $\$ 2.7$ billion) being allocated to budget support. The Board of Directors emphasized (electronic resource): "The program is subject to exceptional risks, especially those arising from the conflict in the East, which may affect the country's ability to sustain stabilization efforts and deliver the structural overhaul needed to resume growth. On the other hand, the crisis provides an opportunity for the government to make a decisive break from the past and implement reform-oriented and sustainable policies with strong ownership. The implementation risks are being mitigated by a critical set of measures adopted as prior actions and by securing broad political support for program objectives and policies. These should help unlock sizable international official assistance and private capital inflows». The program was based also on strong international assistance and partial public debt restructuring to narrow the wide financial gap and use these resources for restoring economic growth.

After the program began, encouraging signs emerged. The exchange rate stabilized, domestic-currency retail deposits began increasing, the pace of economic decline slowed and the authorities made a strong start in implementing the economic program.

On July 31, the Executive Board completed the first review of Ukraine's Extended Arrangement under the Extended Fund Facility (EFF), thus opening the door to the disbursement of SDR 1,182.1 million (about US\$1.7 billion), which would bring total disbursements under the arrangement to SDR 4.72 billion (about US $\$ 6.68$ billion).

Five months into 2016 the macroeconomic situation in Ukraine has improved substantially. The economy has started to grow; inflation has fallen to single digits, while the overall balance of payments has been in line with the 2015 program. After a long delay associated with a late 2016 budget approval and following a government crisis, the Fund's mission Ukraine in May 2016 reached staff-level agreement with Ukrainian authorities for preconditions and policies. The second review under the EFF was approved in September 2016,. The staff noted considerable progress in restoring macroeconomic stability and shining structural reforms under difficult conditions. In December 2016 Ukrainian authorities nationalized the country's troubled largest commercial bank Pryvatbank, whose financial stability was at risk. This had been the main precondition for the third review of the EFF program, planned for March 2017. Nevertheless, acceleration of structural reforms and the fight against corruption continue to be crucial for achieving program objectives. 


\section{Conclusions}

The complex program reforms agenda for Ukraine is necessity to accelerate inclusive economic growth (electronic resource) with strong fundamentals and macroeconomic stability support. Monetary policy could focus on the price stability with simultaneous efforts to rebuild foreign buffers.

Second pillar of Central bank activity is to support financial stability. Rapid restoring of banking system health and facilitating the massive lending to the economy are welcome. NBU's independence is key factor for it.

Pension system needs to reform drastically on sound financial basis. Tax reforms should focus more on the tightening tax collections with simultaneous simplification of the tax regime instead sharp tax cuts. The energy prices should be oriented on the market level to be protected against high energy subsidies from government budget to real sector.

Also, the acceleration of structural reforms and the fight against corruption, namely the introduction of land reform, privatization of loss-making state-owned enterprises and the creation of an anti-corruption court, continue to be crucial for the next revision and achievement of the program's goals in general.

\section{References}

1. IMF factsheet IMF Quotas, 2017, http://www.imf.org/About/Factsheets/ Sheets/2016/07/14/12/21/IMF-Quotas?pdf=1.

2. Crisis Program Review, SM/15/277, IMF, Washington DC.

3. Petryk, O. (2013). Main Aspects of Macroprudential Policy in the Modern Reality, Herald of the National Bank of Ukraine, №9 (211), NBU, Kyiv.

4. Petryk, O., Batkovskyi, V. (2014). Financial programs of the International Monetary Fund for providing financial assistance to countries, Herald of the National Bank of Ukraine, N 6 (220), NBU, Kyiv.

5. Mohsin, S. Khan, Sunil Sharma, (2001). IMF Conditionality and Country Ownership of Programs, IMF Working paper, WP/01/142, IMF, Washington DC.

6. Goldsbrough, D., (2015). Independent Evaluation Office of the International Monetary Fund Review of Ex Post Assessments of Countries with LongerTerm Program Engagement and of Ex Post Evaluations of Exceptional Access Arrangements, IEO Background Paper, BP/15/01, IMF, Washington DC.

7. IMF Financial Operations -170 pages, IMF, Washington DC. 

and the implications and prospects for Ukraine

8. Jeffrey Sachs, (1997). The IMF Is a Power Unto Itself, The Financial Times, December, 111997.

9. Joseph E. Stiglitz., (2002). Globalization and its Discontents. New York: W.W. Norton, Print.

10. 2014, Ireland, Ex Post Evaluation of Exceptional Access Under the 2010 Extended Arrangement, IMF Country report No. 15/20, IMF, Washington DC.

11. 2007, Uruguay: Fifth and Sixth Reviews Under the Stand-By Arrangement, Requests for Waiver of Nonobservance of Performance Criteria, and Financing Assurances Review -Staff Report; Staff Supplement; Staff Statement; Press Release on the Executive Board Discussion; and Statement by the Executive Director for Uruguay, IMF Country Report No. 07/146, IMF, Washington DC.

12. 2008, Uruguay: Ex Post Evaluation of Exceptional Access Under the 2005 Stand-By Arrangement, IMF Country Report No. 08/47, IMF, Washington DC.

13. 2012, Romania: Ex Post Evaluation of Exceptional Access Under the 2009 Stand-By Arrangement, IMF Country Report No. 12/64, IMF, Washington DC.

14. 2014, Romania: Ex post evaluation of exceptional access under the 2011 Stand-by Arrangement, IMF Country Report No. 14/88, IMF, Washington DC.

15. 2011, Ukraine: Ex Post Evaluation of Exceptional Access Under the 2008 Stand-By Arrangement, IMF Country Report No. 11/325, IMF, Washington DC.

16. 2014, Ukraine: Ex Post Evaluation of Exceptional Access Under the 2010 Stand-By Arrangement, IMF Country Report No. 14/146, IMF, Washington DC.

17. 2014, Ukraine: Request For a Stand-by Arrangement-Staff Report; Staff Supplements; Press Release on the Executive Board Discussion; and Statement by the Executive Director for Ukraine, IMF Country Report No. 14/106, IMF, Washington DC.

18. 2015, Ukraine, Request For Extended Arrangement Under The Extended Fund Facility And Cancellation Of Stand-by Arrangement-Staff Report; Press Release; And Statement By The Executive Director For Ukraine, No. 15/69, IMF, Washington DC

19. 2015, Ukraine, First Review Under The Extended Arrangement-Press Release; Staff Report; And Statement By The Executive Director For Ukraine, No.15/218, IMF, Washington DC.

20. 2017, Ukraine, 2016 article IV Consultation and Third review Under The Extended Arrangement, Requests, For a Waiver Of Non-observance of Applicability, Rephasing of Access And Financing Assurances Review-Press Release; Staff Report; And Statement by The Executive Director For Ukraine, No. 17/83, IMF, Washington DC. 